\title{
The valid publication of Monolophus (Zingiberaceae) revisited
}

\author{
J.F. Veldkamp \\ Naturalis Biodiversity Center, P.O. Box 9517, \\ 2300 RA Leiden, The Netherlands \\ jef.veldkamp@naturalis.nl
}

\begin{abstract}
The nomenclatural history of Monolophus Delafosse, Guill. \& J.Kuhn is discussed. The combinations Monolophus picheansoonthonii (Phokham \& Prasarn) Veldk. and Monolophus pubescens (Picheans. \& Phokham) Veldk. are made.
\end{abstract}

Keywords. Kaempferia, new combination, nomenclature, Wallich

\section{Introduction}

Mood et al. (2014) argued that Monolophus (Zingiberaceae) was validated by Wallich (1832), having first been mentioned by Wallich (1830: April) in the second issue of the Plantae Asiaticae Rariores. However, the name was validated earlier. There is a review of Wallich's book by Guillemin (1830: July) in the Bulletin des Sciences Naturelles et de Géologie. The French text for Kaempferia elegans Wall. is a more or less summarised translation of that by Wallich (1830) and thus Monolophus is not validated in this work: "suffirait peut-être pour éloinger cette plante du Kaempferia... en former un genre sous le nom de Monolophus”.

On page 31 of the Index in the next volume of Bulletin des Sciences Naturelles et de Géologie, published in October 1830 (fide printers mark on p. [1] of the issue) Monolophus is mentioned without an author and with the comment "Genre nouveau de Scitaminées" [New genus of the Scitaminae]. This may be regarded as an acceptance and validation of the name here. Wallich as the original author was not mentioned.

The journal was edited by [G.] Delafosse [mineralogist], [J.B.A.] Guillemin [botanist] and [J.] Kuhn [zoologist] and the name is, therefore, to be cited as: Monolophus Delafosse, Guill. \& J.Kuhn, Bull. Sci. Nat. Géol. 23, Index: 31 (October 1830).

Mood et al. (2014) have shown that Kaempferia elegans is not a suitable candidate for the lectotype of Monolophus. Yet, Picheansoonthon (2016) erroneously maintained it as such. He also, mistakenly, thought that the new combinations in Monolophus by Mood et al. are illegitimate, which is against Art. 55.1 of the ICN (McNeill et al., 2012).

A proposal to conserve Caulokaempferia K.Larsen by Inthararapichai et al. (2014) has not yet been considered by the appropriate committee. Since the publication 
of Mood et al. (2014) two new species of Caulokaempferia have been published. These are here transferred to Monolophus.

Monolophus picheansoonthonii (Phokham \& Prasarn) Veldk., comb. nov. Caulokaempferia picheansoonthonii Phokham \& Prasarn in Phokham et al., J. Jap. Bot. 90: 155, t. 1, 2 (2015). - TYPE: South-western Thailand, Kanchanaburi, Sankhla Buri Distr., Thung Yai Narasuan Wildlife Sanctuary, Mt Kulu Huamee, near Ro Kee stream, 15²'97.4"N 98'29'58.2"E. CP [Chayan Picheansoonthon] 160814-1 (holotype BK).

Monolophus pubescens (Picheans. \& Phokham) Veldk., comb.nov.-Caulokaempferia pubescens Picheans. \& Phokham in Phokham et al., Taiwania 60: 77, t. 1, 2. (2015). TYPE: Northern Thailand, Mae Hong Son, Mueang Mae Hong Son Distr., CP [Chayan Picheansoonthon] 130713-3 (holotype BK).

ACKNOWLEDGEMENTS. Dr K. Gandhi (A), Mr R. Govaerts (K), an anonymous reviewer, and Dr D.J. Middleton (SING) are much thanked for their critical comments and constructive help.

\section{References}

Delafosse, G., Guillemin, J.B.A. \& Kuhn, J. (eds) (1830). Index. Bull. Sci. Nat. Géol. 23: 25, 31. Guillemin, J.B.A. (1830). \# 43. Plantae Asiaticae Rariores. Bull. Sci. Nat. Géol. 22: 68-69, 76. Intharapichai, K., Phokham, B., Wongsuwan, P. \& Picheansoonthon, C. (2014). The genus Caulokaempferia (Zingiberaceae) in Vietnam. J. Jap. Bot. 89: 129-136.

McNeill, J., Barrie, F.R., Buck, W.R., Demoulin, V., Greuter, W., Hawksworth, D.L., Herendeen, P.S., Knapp, S., Marhold, K., Prado, J., Prud'homme van Reine, W.F., Smith, G.F., Wiersema, J.H. \& Turland, N.J. (2012) International code of Nomenclature. Regnum Veg. 154.

Mood, J.D., Veldkamp, J.F., Dey, S. \& Prince, L.M. (2014). Nomenclatural changes in Zingiberaceae: Caulokaempferia is a superfluous name for Monolophus and Jirawongsea is reduced to Boesenbergia. Gard. Bull. Singapore 66(2): 215-231.

Phokham, B., Intharapichai, K., Wongsuwan, P. \& Picheansoonthon, C. (2015). Caulokaempferia pubescens (Zingiberaceae) - a new species from northern Thailand. Taiwania 60: 77-80.

Phokham, B., Prasarn, S., Sangnark, S. \& Wongsuwan, P. (2015). A new species of Caulokaempferia (Zingiberaceae) in western Thailand. J. Jap. Bot. 90: 153-157.

Picheansoonthon, C. (2016). Nomenclatural controversy between Caulokaempferia and Monolophus (Zingiberaceae). Fol. Malaysiana 17: 67-74.

Wallich, N. (1830). Plantae Asiaticae Rariores 1: 24, t. 27. London: Treuttel \& Würz.

Wallich, N. (1832). A Numerical List of Dried Specimens of Plants in the East India Company's Museum, collected under the superintendence of Dr. Wallich, of the Company's Botanic Garden at Calcutta (The Wallich Catalogue). \# 6591-6593. 